\title{
The origins of the Bamiléké hedgescape "bocage". Development from 1900 to 1960
}

Les origines du bocage Bamiléké. Développement de 1900 à 1960

Denis Gautier, Dirk Verboven and David Andrew Wardell

\section{(2) OpenEdition}

\section{Journals}

Electronic version

URL: http://journals.openedition.org/cybergeo/28896

DOI: $10.4000 /$ cybergeo.28896

ISSN: 1278-3366

\section{Publisher}

UMR 8504 Géographie-cités

Brought to you by Institut de recherche pour le développement (IRD)

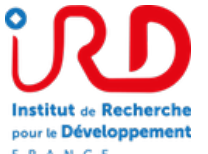

pour le Développerment

Electronic reference

Denis Gautier, Dirk Verboven and David Andrew Wardell, «The origins of the Bamiléké hedgescape " bocage". Development from 1900 to 1960 », Cybergeo : European Journal of Geography [Online], Space, Society, Territory, document 835, Online since 16 November 2017, connection on 18 January 2018. URL : http://journals.openedition.org/cybergeo/28896; DOI : 10.4000/cybergeo.28896

This text was automatically generated on 18 January 2018

(c) CNRS-UMR Géographie-cités 8504 


\title{
The origins of the Bamiléké hedgescape "bocage". Development from 1900 to 1960
}

\author{
Les origines du bocage Bamiléké. Développement de 1900 à 1960
}

Denis Gautier, Dirk Verboven and David Andrew Wardell

\section{Introduction}

1 Research on the Bamiléké bocage in western Cameroon began long ago. Geographers were curious about the formation of this landscape, which is so unusual for the tropics (Champaud, 1983; Dongmo, 1981; Fotsing, 1998; Gautier, 1994a; Hurault, 1970b). Many of them wrote about the bocage, a hedgescape that crisscrossed the sloped farmlands with hedges, copses and trees used for various purpose like routing animals, demarcating allocated lands, as a source of forest products like wood, fodder or fruit, preserving biodiversity in anthropized environments or as windbreaks. The network of planted hedges of varying density was used as lanes to guide livestock, to stake out user rights and to provide households with a variety of forest products. But despite the abundance of information, not much is known about the origin of these "hedgescapes" (bocage).

The purpose of this paper is not to list and rank the factors that determined the installation of the network of hedges but rather to understand which of the changes made to the wooded landscape in the $20^{\text {th }}$ century was the result of farmers' innovation and which were the result of foreign influences. To answer these questions, we conducted a review of the literature and learned what we could from the oral tradition and from our analysis of the tree formations whose social representation, functions and outputs between 1990 and 1992 we studied by consulting hundreds of open anthropological interviews, landscape structure analyses and ethnobotanical surveys. This led us to study trees as part of the agrarian systems. Rather than considering woodland formations individually, we viewed them as part of a global management system administered by the farmers and their society. With this in mind, we decided not to study the evolution of the 
hedgescape (bocage) alone, but to extend the study to include wooded slopes, regardless of whether the tree was intercropped or whether it was used as a border for these landscapes.

3 We studied the time period from the arrival of the first Europeans in the Bamiléké region (around 1900) to when Cameroon became independent in 1960. Warnier $(1984,1985)$ published a reference study on the evolution of the landscape before that period. More recent history is available in many publications (Dongmo, 1981; Fotsing, 1998; Gautier, 1992). As far as possible, the written sources used in this study only concerned the Dschang region, more specifically the Bafou chiefdom, where we did our fieldwork.

We distinguish between four time periods we feel correspond to evolutionary phases in the wooded landscapes: the arrival of the Europeans (1900-1915), from European pacification to the liberalisation of the coffee trade (1915 to 1945), the period of liberalised coffee trade (1945 to 1960), and the period of havoc at the time of independence (around 1960).

\section{The Bamiléké landscape when the Europeans arrived (1900-1915): expansion of hedges starting from the chiefdoms}

5 When the Europeans arrived in the Bamiléke region in 1900, the landscape mainly resembled a savanna, with the chiefdoms surrounded by a dense network of hedges, houses and fields enclosed by living fences at the bottom of the slopes, but no real system of enclosures to separate the grazed fallows from the cultivated lands, and no fencing in uninhabited areas.

6 Ghomsi (1972) dates the origins of the hedgescape (bocage) in the Bamiléké region to the 19th century. That is when the "growing population in the chiefdoms occupied the whole territory" and "each family generally demarcated its property by enclosing it with a living hedge". This is the hypothesis used as the basis for work on the dynamics of the bocage landscape in the high plateaux of West Cameroon (Dongmo, 1983; Pillot, Lauga Sallenave, \& Gautier, 2002), which combines the expansion of the bocage with the increase in population pressure. For instance, Barbier (1981), wrote: "at the beginning of the 19th c., the occupation of the space on the Bamiléké plateau was reaching completion, hence the consequences of the arrival of people to join the Bamiléké groups that are already installed will be: the intensification of agriculture and small livestock production, which will mean bocage on basaltic soils or (people) descending from the plateau and moving into the forest" (p. 347).

7 To support this hypothesis, we try to analyse the writings of the first Europeans, the discourse of the Bamiléké collective memory and botanical data.

\section{The first contacts with the Germans between 1900 and 1910: the conquest and the scientific expeditions}

8 Dr. Zintgraff reached Bali, which is now in the English-speaking part of Cameroon, in January 1889. 
Picture 1: German explorer Eugen Zintgraff and Galega I, fon of Bali, Cameroon. (Source: History of Cameroon Since 1800 by Victor Julius Ngoh)

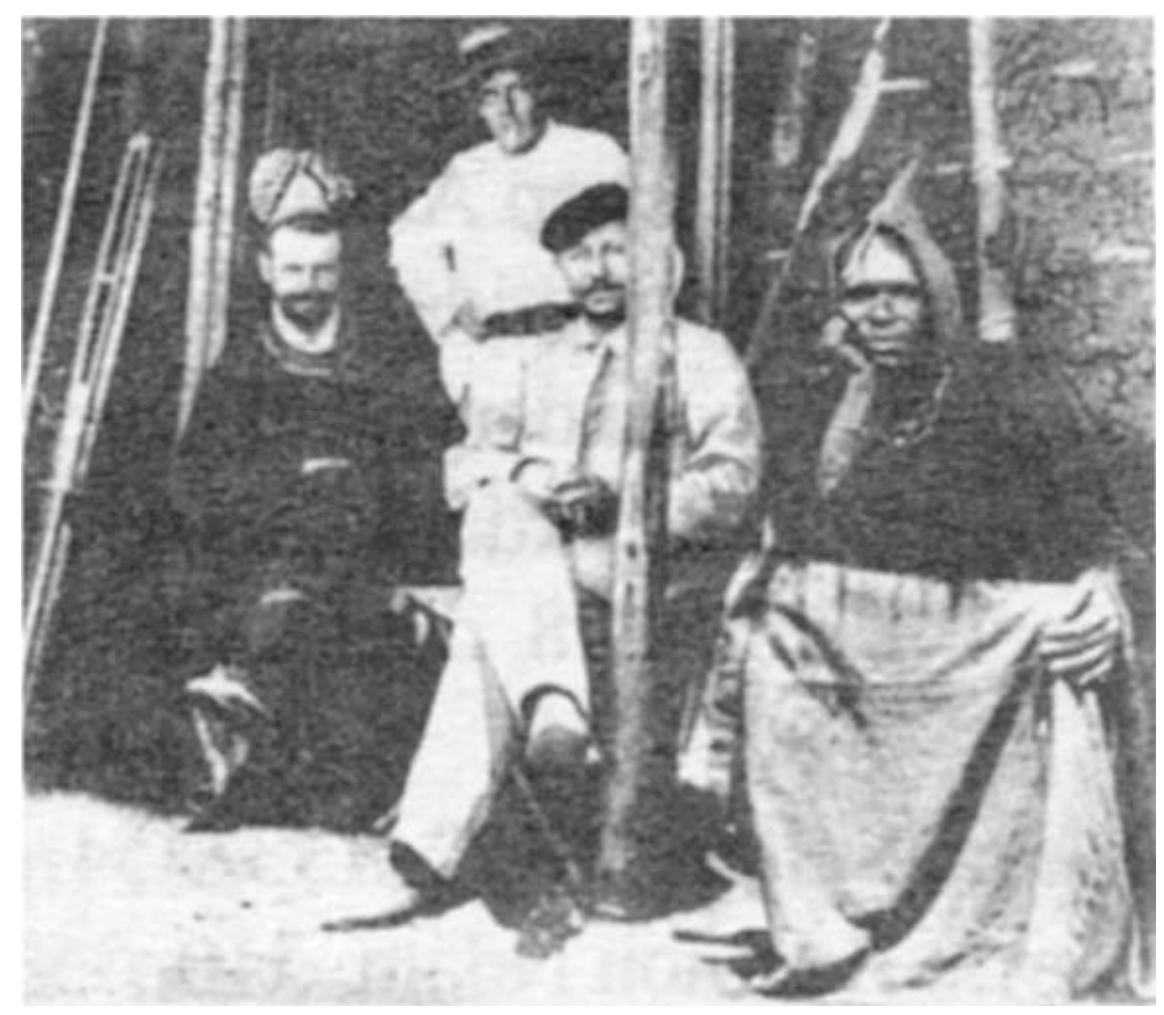

9 A military expedition against the Bangwa, the Bafut, and the Bandeng in 1901 headed by Lt. Pavel led to the establishment of a fort at Fontemdorf, (Fontem Lepang in the Bafou language) in western Bamiléké. Bamenda was founded in 1901 after the pacification of the Bafut and the Bandeng (Nkwi, 1989). In 1903, Dschang, which was founded in 1892-93 very close to the Bafou chiefdom, became a military post that replaced Fontemdorf (Fig. 1). Lieutenant Strümpell, based in the Bamenda fort, began visiting the northern Bamiléké chiefdoms in 1902. 
Fig 1. Map of Bamiléké in Cameroon showing the locations cited in the text

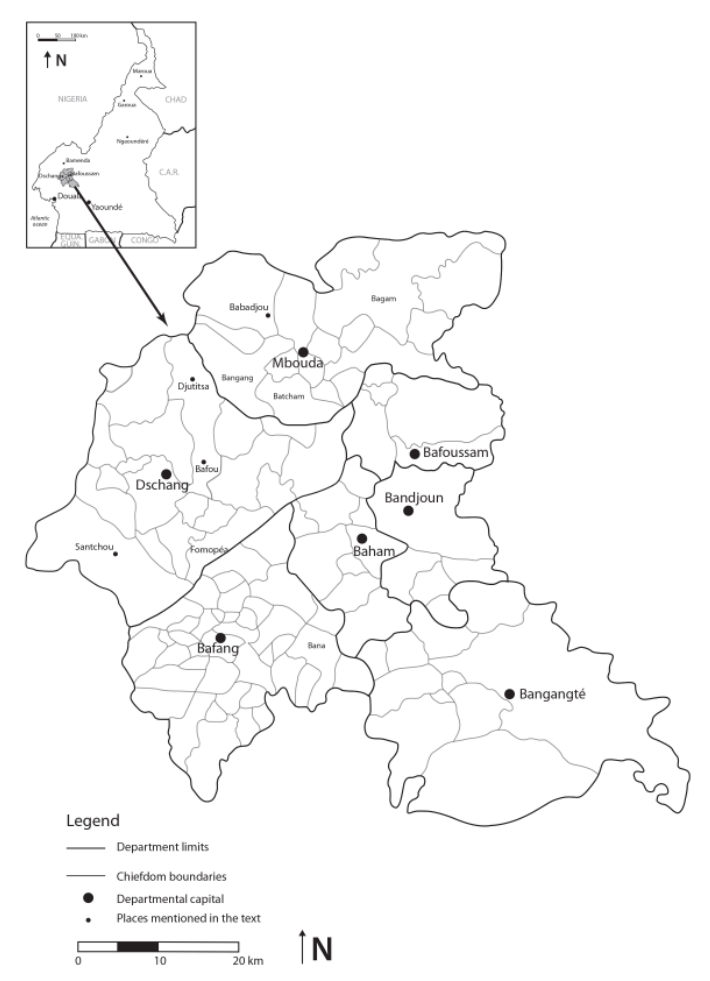

These military expeditions were followed by the first exploratory expeditions and journeys, while the pacification of the region continued.

- In 1905 (1904?) the Manengouba expedition led by Colonel Müller reached Fomopéa, south of Dschang (Fig. 1);

- Glauning, headed an expedition to Bali-Bameta and to the southern sector;

- In 1908, Prof. K. Hassert and Prof. F. Thorbecke conducted a geographical research expedition to the region between Dschang and Bamenda (Hassert, 1908);

- J. Ittmann described the visit of two German officers to the Bandjoun chiefdom (Fig. 1), sometime between 1905 and 1910 (Ittmann, 1925);

- In (1909?) 1910, the Nkam-Noun expedition, led by Rausch, left Dschang to pacify the region;

- In 1908-1909, a botanical/zoological expedition passed through the Mbo plains, Dschang, Bamenda, etc. (Ledermann, 1912);

- In 1907-1909, the first ethnographic expedition, led by Bernhard Ankermann travelled through Grassfields but not through Bamiléké county where the population was hostile (Ankermann, 1910 p. 292)

- In 1911, an in-depth geological investigation was conducted in the Dschang district (Mann, 1912)

- At the end of 1911, F. Thorbecke travelled through Santchou, Dschang, and Bana (see Fig. 1) (Thorbecke, 1914);

- In 1912, J. Emonts travelled from Fongodera to Babadju, via Dschang (Fig. 1) (Emonts, 1922);

- In 1917, K. Hassert (1917)published a summary of German geological, botanical and zoological data;

- In 1917, A. Calvert (1917) published a book on Cameroon containing excellent photographic records of Bafu-Fondong, among others. 
Picture 2: Chief Bafu-Fondong on his Throne. Source Calvert, 1917

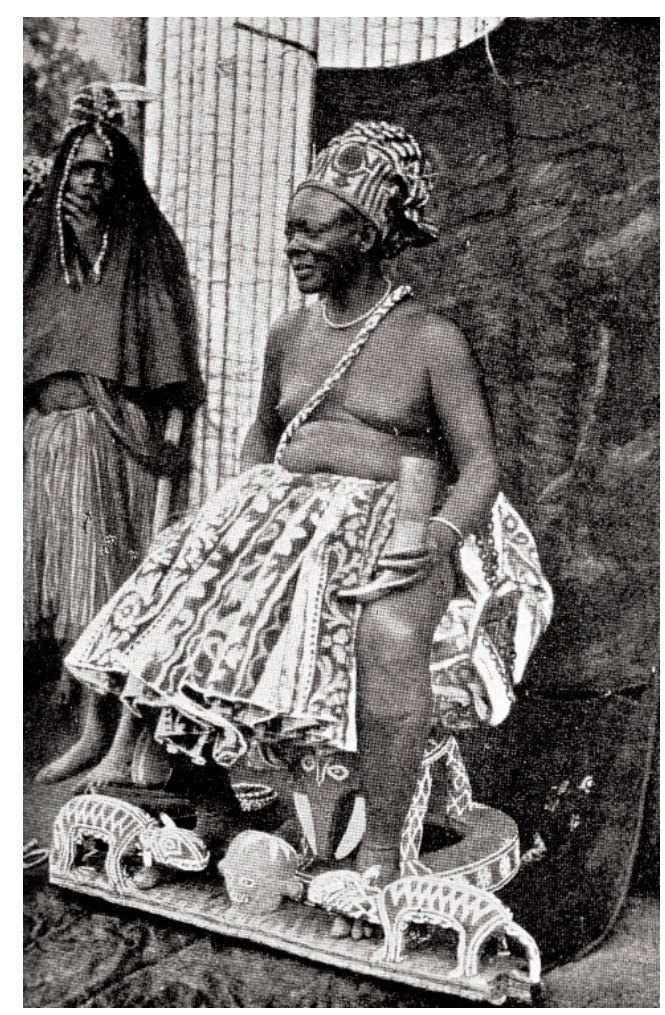

11 After 1910, after the Bamiléké region was conquered came the - short - period of German administration. The traditional political organisation remained mostly unchanged, but certain "collaborating" chiefs were given more power when several small chiefdoms were combined and placed under the authority of a senior chief who accepted colonial rule; this said, the small "absorbed" chiefdoms remain relatively independent ${ }^{1}$. The boundaries of the chiefdoms were established, and border disputes between the chiefdoms tended to subside when the Europeans arrived.

\section{The first descriptions of the Bamiléké landscape}

12 Important information on the landscape can be obtained from the writings of the first members of the military, explorers and travellers. Since the Bamiléké had no political or economic relations with the Germans at that time, there are no descriptions of Bamiléké landscape in the German colonial literature (Dippold, 1973). We have included some excerpts of these writings ${ }^{2}$ in the footnotes but what is most important is the overall picture obtained from this literature. When the Europeans settled in the Bamiléké region, they described the landscape as follows:

- the Dschang region is already quite populated, but there are still open spaces: the "countryside" and the hill tops;

- the main picture of the land is savanna covered with trees;

- a dense network of hedges encircles the chiefdoms;

- houses are scattered around these groves of hedges and are located at the bottom of the slopes, near the streams; the houses together with the cultivated plots form an area that is enclosed by living fences; the hedges only seem to be planted around the houses and the fields; 
- the colonisers live in districts (like Djutitsa in Bafou) (Fig. 1) that are surrounded by huge vacant lots and have their own fencing system, far from the historical centre of the chiefdoms.

\section{The effects of the German administration and the German missions}

From a military and administrative point of view, the Bamiléké territory was hardly pacified under the German administration. The civilian administration was only set up in Dschang in $1912^{3}$. In 1915, the German era came to an end, and the French era started.

Although the region had not yet begun developing its economy when the French arrived, the fertility of the volcanic soils was no secret ${ }^{4}$. Earlier, in 1889-1899 the North-West Cameroon Company (Gesellschaft Nordwest-Kamerun) obtained concessionary rights to an area of almost $100,000 \mathrm{~km}^{2}$ to exploit the northwest Cameroon plateaux, but lost the concession in 1910 due to financial problems (Eyongetah Mbuagbaw, Brain, \& Palmer, 1974; Gann, 1975; Hausen, 1970).

The main German achievement was the construction of infrastructure, especially roads, with the "help" of the local population (Hausen, 1970 p. 186). For the German colonisers, agriculture and livestock production simply meant:

- encouraging the production of cattle by setting up the Djutitsa farm in Bafou near Dschang in 1909 (Dongmo, \& al., 1990)

- promoting oil palm cultivation and distribution, although they knew that for ecological reasons Elaeis guineensis did not grow well at altitudes above 1000 meters i.e., most of the Bamiléké plateau.

The agricultural school in Dschang was created in 1909 mainly:

- to introduce potato cultivation, and

- to introduce the use of draught animals.

17 Woody species were not studied, and agricultural extension activities had little effect on the structure of the landscape. Protestant and Catholic churches were built as of $1903^{5}$. The pastors' main activity was evangelisation and schooling in the "local" languages (actually all the missions used the Bali language), but neither activity covered a large area ${ }^{6}$.

\section{The oral tradition}

18 It is difficult to rely on the collective memory for a period dating back nearly a century. Asking in 1990 an old person to tell us about the countryside in 1900 did not provide us with reliable information since that period of time already seemed mythical or ancient to him. To try to prove our hypothesis, we needed precise, not fuzzy information. Ethnologists can reactivate memory by working on a type of detailed historical reconstruction based on selected cases and supported by data on personal history, genealogy, etc. But this requires a procedure that takes more time than we had at our disposal. Fortunately, J.H.B. den Ouden made this type of a reconstruction for land use in 
two chiefdoms (Batcham and Bangang, Fig. 1) located near Dschang and Bafou (Den Ouden, 1980, 1981).

19 We were able to draw the following conclusions from this historical reconstruction and apply them to the pre-1915 period:

- A chiefdom was composed of 'quarters' (quartiers in French) separated by swamps or hills that were not cultivated ${ }^{7}$;

- The houses in these quarters were built close together down in the valleys';

- Only a small part of the land was continuously cultivated, but this did not prevent an individual farmer from having the right to use the land';

- The inhabited and cultivated parts of the concession were practically invisible from the roads along the hillcrests ${ }^{10}$; in one example studied by den Ouden (1981) the beginning of the cultivated lands was 400 metres down the hill!

- The cultivated areas were fenced, but there was no real system of enclosures to separate the grazed fallows from the cultivated lands ${ }^{11}$.

20 Although no specific mention is made of the living fences, the data produced by den Ouden confirms the observations made by the first Germans.

\section{What do the trees have to say?}

The history of the hedges, which are multi-species and multi-purpose (Gautier, 1994b) is hard to describe from a botanical point of view. Their age, composition and structure depended on their targeted use, i.e., they were selectively cultivated to meet the concession's needs for the forestry products, the need to protect the crops from livestock, and to protect them from the eyes of curious neighbours. Some well-structured trees were grown to produce fruit and/or industrial and utility-grade timber. Most of the wooded components of the hedges and fences were trimmed to the height of a person and to produce cuttings for replacements and fuelwood. Competition between the trees and the crops was limited. Pollarding the hedges kept their aboveground parts at a juvenile stage with ample ligneous production to meet the concession's need for wood. When the trees grew old, they were sometimes rejuvenated by clearcutting and covering with copses, but this type of cut was seldom used because it created an opening in the living fence that allowed small livestock to stray. The cut took place shortly after large herds/ flocks of small livestock were no longer reared on the land.

Under these conditions, it was difficult to assess the real age of the hedges. It is possible to estimate the age of trees using ring measurements of the stumps although this technique is not very informative in the tropics where there is little variation in interseasonal growth. Nonetheless, this is what we tried to do. The problem was finding clean cut stumps. This was possible with Eucalyptus and other species which are generally planted for reforestation and are felled using a chainsaw. However, the results had little bearing on our study since "the whiteman's trees" were planted at the same time as the coffee plants, i.e. around 1925. We managed to find a small number of trees that were planted around that date despite the growing demand for Eucalyptus wood. This technique cannot be used for local species because the trees are cut down by axe, and the stumps are not clean cut. It was out of the question for us to ask any farmer to cut down a tree so that we could evaluate its age. 

measures were made on trees in the hedges (Gautier, 1989) to estimate the general growth curve. To estimate the age of the tree, measurements have to be made of the diameter at the base of the tree. Height has no meaning for trees used in these operations. Some trees, particular in the hedges in the lower areas of the concession, are over 100 years old (Canarium schweinfurthii, Dacryodes edulis, Pseudospondias microcarpa). But there is no evidence that they were planted when the hedges were being installed. They might have been spared when the houses were built down in the valley, i.e., before the turmoil of the independence period and their relocation higher up for safety reasons. When the border hedges were planted around the concessions, these trees may have served as pillars to strengthen the hedges and delineate the borders. were planted as cuttings to create hedges, which were sometimes composed of only one species. They were generally planted in the direction of the longest slope, and delineated the boundaries.

Picture 3: Old hedge of Dracaena arborea (source: Gautier, 1991)

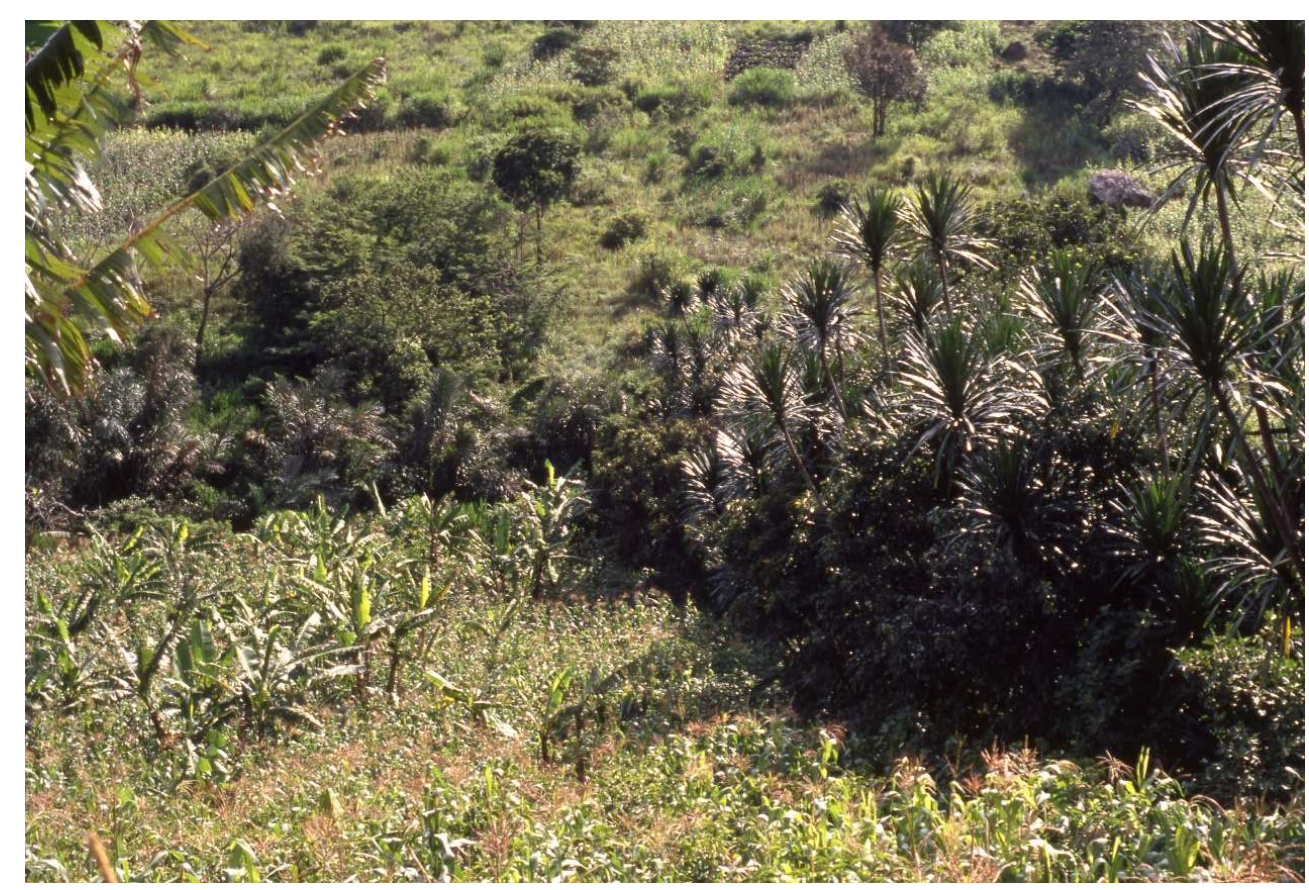

Dracaena arborea are "strong trees" that are difficult to uproot and can be used to avoid land tenure disputes. They are the most frequent trees in the hedges and are mentioned in early writings (Albert, 1937; Despois, 1945; Hedin, 1930). Because of competition with the crops, they are no longer being planted, but their age is easy to assess. The oldest ones that were still standing in 1990 and were part of the hedgescape, were between 70 and 100 years old in 1990 in other words, they predated the time the Europeans settled the Bamiléké plateau. These trees are located on the borders of the Raffia palm groves and are planted upslope to delineate the concession. This description is also found in ethnographic studies.

To our knowledge, Ledermann (1912) was the first botanist collect plants in the region, in December 1908. Since he was mainly interested in the mountain forests of Mount 
Bamboutos, the information he provided on the hedges in very incomplete, but nevertheless precious:

- Around Dschang and Djutitsa, he saw an enclosure system based on Ficus spp., Dracaena arborea, Spathodea campanulata, as well as trees that rooted easily which he did not identify;

- In the areas that were cultivated but not fenced, (probably left fallow since Lederman went through the Bamiléké area in December, during the dry season), he found large numbers of Cola acuminata (renamed anomala), Polyscias fulva and Spathodea campanulata species;

- In the savanna, he noted the presence of occasional trees belonging to: Albizzia spp., Entada abyssinica, Faurea speciosa, Protea sp., Vernonia sp., Tephrosia vogelii; he also noted the presence of Ceiba pentendra, Dracaena arborea and Ficus spp.

His partial inventory confirms the existence of trees planted as hedges by the Bamiléké farmers and that are still used to design hedges today. The presence of some isolated trees that represented power, like Ceiba pentendra, or land ownership like Ficus spp. and Dracaena arborea in the savanna in 1908, lead us to believe that territorial land was appropriated before it was actually developed.

\section{Bamiléké landscape at the beginning of the $20^{\text {th }}$ century}

By crossing fragmentary and sometimes anecdotal information, we built the following hypothesis on the organisation of the Bamiléké landscape at the beginning of the $20^{\text {th }}$ century when the Europeans arrived:

1. Hedgescapes (bocage) existed before the arrival of the Europeans. Planting hedges was not imposed or even encouraged by the colonial rulers or the missionaries. They already existed. In 1908, Ledermann found species that were basic to the construction of hedges.

2. However, the type of bocage differed from what it is today and was not found everywhere, which thus challenges a generally accepted hypothesis (Barbier, 1981; Ghomsi, 1972). The lands were covered with widely spaced groups of scattered houses gravitating around the original chiefdoms with a labyrinth of hedges around the chief's living quarters, plus more widely dispersed houses that enclosed the concession chief's fields in the most densely populated areas, and no fencing in uninhabited areas. These groups of houses were separated by vast stretches of savanna over which rival chiefdoms fought.

Bocage, at that time, amounted to islets clustered around the chiefdoms and reflected the population density of the historic core groups. There was no dominant landscape element in the Bamiléké area at the time, just patches in a savanna system interspersed with gallery forests. This analysis would explain the relative ease of German penetration despite the fact that population density was already rather high. The region looked like a savanna landscape because the enclosed lands and houses were at the bottom of the valleys and could not be seen from the hillcrest roads along which the first Europeans travelled.

The Bamiléké landscape was changing fast into a hedgescape (Fig. 2). There was still room available for expansion: between the quarters and between the chiefdoms, there were vast stretches of land waiting to be cultivated, interspersed with long-term fallows (Mann, 1912). Some of the quarters, such as Djutitsa in Bafou, had been colonised. On the other hand, most of the uninhabited lands had already been distributed and the best lands had been taken over even before they were cultivated. This land appropriation is signalled by symbolic trees (Ledermann, 1912) or by stones that may have temporarily played the notification role (Buell, 1965 (1928); Hassert, 1917). 
Fig. 2: Graphic representation of the Bamiléké landscape before European pacification

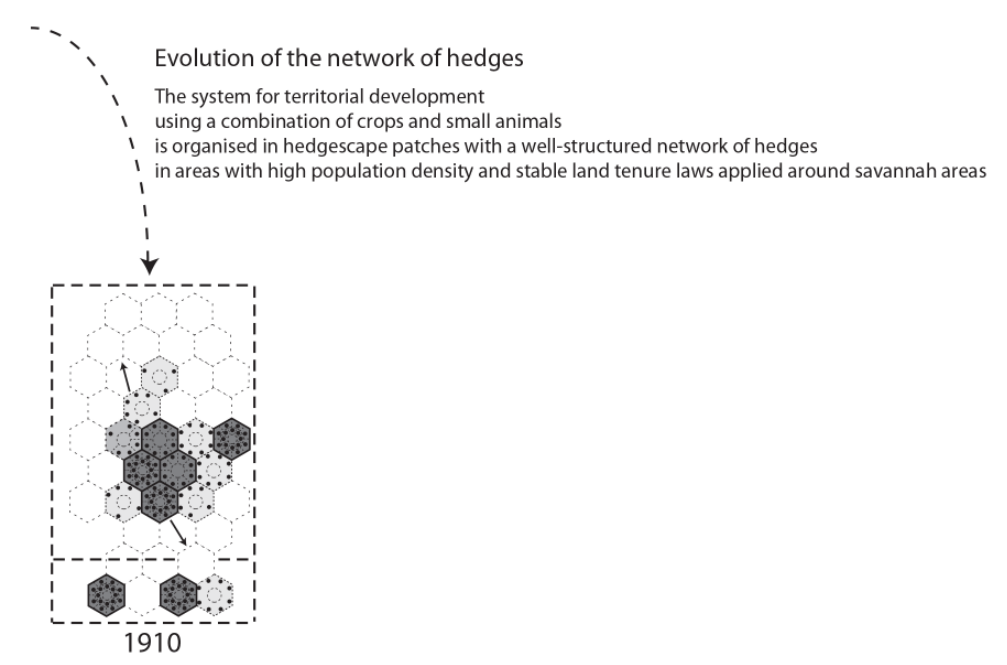

Legend:

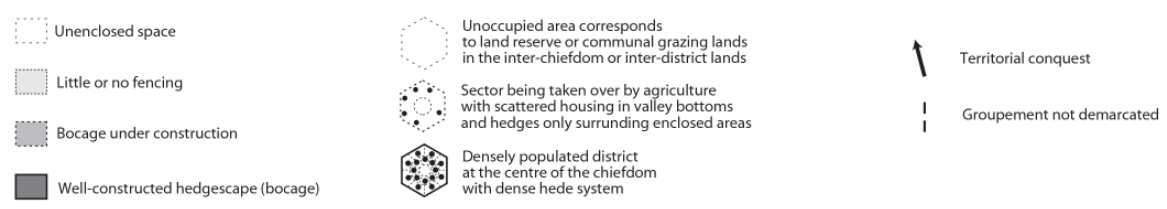

31 In this and the following figures, chiefdoms and districts are represented by hexagons to best match the hilly terrain where the population settled, with strips of concessions around the hill, and houses in the valley bottoms at the beginning of the $20^{\text {th }}$ century (Fig. 2) and later at mid-slope (Fig. 3 and 4).

\section{From European pacification to coffee trade liberalisation (1915-1945): involution of the bocage}

The presence of the French between 1915 and 1945 led to: the pacification of the region and the establishment of permanent boundaries between the chiefdoms; the acceleration of population growth and the associated need for more land; displacement of people's houses up the hill, which gave the impression of nearly continuous housing along the roads. The key elements of the changes in the landscape were cultivated lands, hedges and fences following the pattern of displacement of the houses; occupation of the vacant lands between the quarters; increased hedge density; networks of hedges extended over nearly all the chiefdoms (except in the "countryside"); reduction of grazing savanna; and gradual occupation of the countryside. The hedgerow system quickly spread and dominated the landscape.

\section{Actions of the French administration and repercussions for the landscapes}

The introduction of the mandate system between the end of the World War I and 1920 led the colonial administration to break up the main chiefdoms created through tribal wars and the regroupings carried out by the German administration (Ghomsi, 1972). 

first they were well received by the chiefs because they were part of the white man's civilisation, but they soon had to cope with two types of problems (Wilbois, 1934).

- the houses were so scattered that it was difficult to install many chapels. It was a fitting turn of history that the Church, in response to the clashes that broke out at independence time, suggested a new regrouping system to the government authorities;

- the reticence of the Bamiléké who continued being pagans, attached to polygamy, which the church condemned (Albert, 1937), and had their own strong social organisation.

- training priests,

- schooling (primary schools),

- the Ad Lucem foundations, which created hospitals (Mveng, 1963). 
42
Jean Despois (1945) summarised these actions as follows: "The Catholic and Protestant missions are rather well liked thanks to their schools and dispensaries/clinics and are not having to face religious hostility as such, but they are finding it difficult to make inroads into such a tightknit society, while there were very few obstacles in the regions of the fetichists." At the beginning of the century, the missionaries did not appear to make any changes to
the landscape, for instance by introducing plants or teaching farming techniques.

43

\section{Botanical data}

Louis Hedin's 1927-1928 botanical mission reported on the wooded landscapes at the end of the 1920s and confirmed the information provided by the missionaries who worked there in the same period.

Like his predecessors ${ }^{16}$, Louis Hedin was interested in the great variety - and exploitation-of the precious wood species in Cameroon. During his travels, he consequently only identified those he judged "worthy of interest".

He felt that the Dschang region, i.e., the savanna where Combretum spp. grows, was not very interesting. He wrote "it is covered with vegetation that reminds me of the Guinean zone, with gallery forests along the river valleys". He appeared to feel that it was a secondary formation caused by land clearing and bushfires by people living in a relatively densely populated area on the high plateau.

He specifically mentioned the valuable forest species in the gallery forests, namely: Chlorophora excelsa, Lophira alata, Pycnantus kombo, Mytragyna macrophylla, all of which had disappeared from the treescape by 1990 (Gautier, 1991).

Outside the gallery forests, he found Canarium schweinfurthii "occasional trees in the Dschang savanna whose edible fruit is sold on the market", and Spathodea campanulata "many isolated trees in the savanna area that has not yet been completely deforested", and also the Cola verticillata (renamed Cola anomala) "commonly found on the hillside in the Bamiléké region". The mention of these trees, which were still abundant in the agricultural system in 1990, was important for the evolution of the treescape.

Hedin also mentioned Ficus and said that some of them were "used as hedges near the little houses". Speaking about Dracaena fragans (or Dracaena arborea), he said "they are abundant in certain parts of the savanna on the Bamiléké plateau. Some of them grow to $15-20 \mathrm{~m}$ in height. The local populations use them as hedges".

Like in the period studied by C. Ledermann (1912), the Ficus and the Dracaena are part of the genus most commonly used in the hedges on the Bamiléké plateau. Surprisingly, Markhamia, which Hedin identified, was not mentioned in the Dschang region, although in 1990 , it was still one of the main species used in the hedges. However, this information confirms the existence of hedges in 1930 which were composed of the same species as the hedges we surveyed in 1990. A forest botanist found some of them sufficiently interesting to report their existence. Later, Despois (1945) pointed out that the appearance of the hedgescape (bocage) in the Bamiléké region could be traced "to the Dracaena and to the numerous and diverse Ficus that the famers use to enclose their fields". 


\section{Changes in the Bamiléké landscape between 1915 and 1945: approaching the classical Hurault image}

51 Writings on the first phase of French colonisation were produced by specialists who were only interested in particular aspects of the landscape: the colonial administrators were concerned by the topography of the region and the political organisation of the Bamiléké people; the missionaries were interested in the social structure and the organisation of the land, which represented an obstacle to their proselytising, while the botanists were only interested in forest species and ignored the anthropic formations on the plateau.

52 Nevertheless, these writings can be used to explain certain trends. The presence of the French between 1915 and 1945 accelerated population growth (Dizain, 1953; Tardits, 1960) and more importantly (Kuczynski, 1939), the related need for more land. Compartmentalisation of the land to form autonomous groups and the rivalry between neighbouring chiefdoms prevented massive population sprawl from occurring in one place although it did contribute to the development of bocage which is only conceivable when land tenure is somewhat secure, as was the case after the region had been pacified.

In 1945, the Bamiléké hedgescapes (bocage) were organised in the same way as they were in 1910, i.e. as an aggregation of concessions models that led to nested chiefdom models at regional scale (Gautier, 1996). But they were spread out and at times contiguous with the centre chiefdom site, which had a dense network of hedges disappearing toward the periphery. The pattern that was taking shape in 1915 is described more systematically in articles by Dizain (1953) and de Lebeuf (1919). When travelling through the Bamiléké region, Lebeuf wrote in France Illustration that "the surprising villages where the faction leaders live are all autonomous centres. There are pathways surrounded by fields bordered by barriers that one can cross via complicated passageways cut off by hedges that are intended to keep wild animals and thieves away. They lead to a royal avenue lined with majestic trees that in turn lead to the home of the Fong". 
Picture 4: Labyrinth of hedges made of cuttings horizontally interconnected with Raffia palm leaves leading to a concession and controlling the movement of livestock (source: Gautier, 1991)

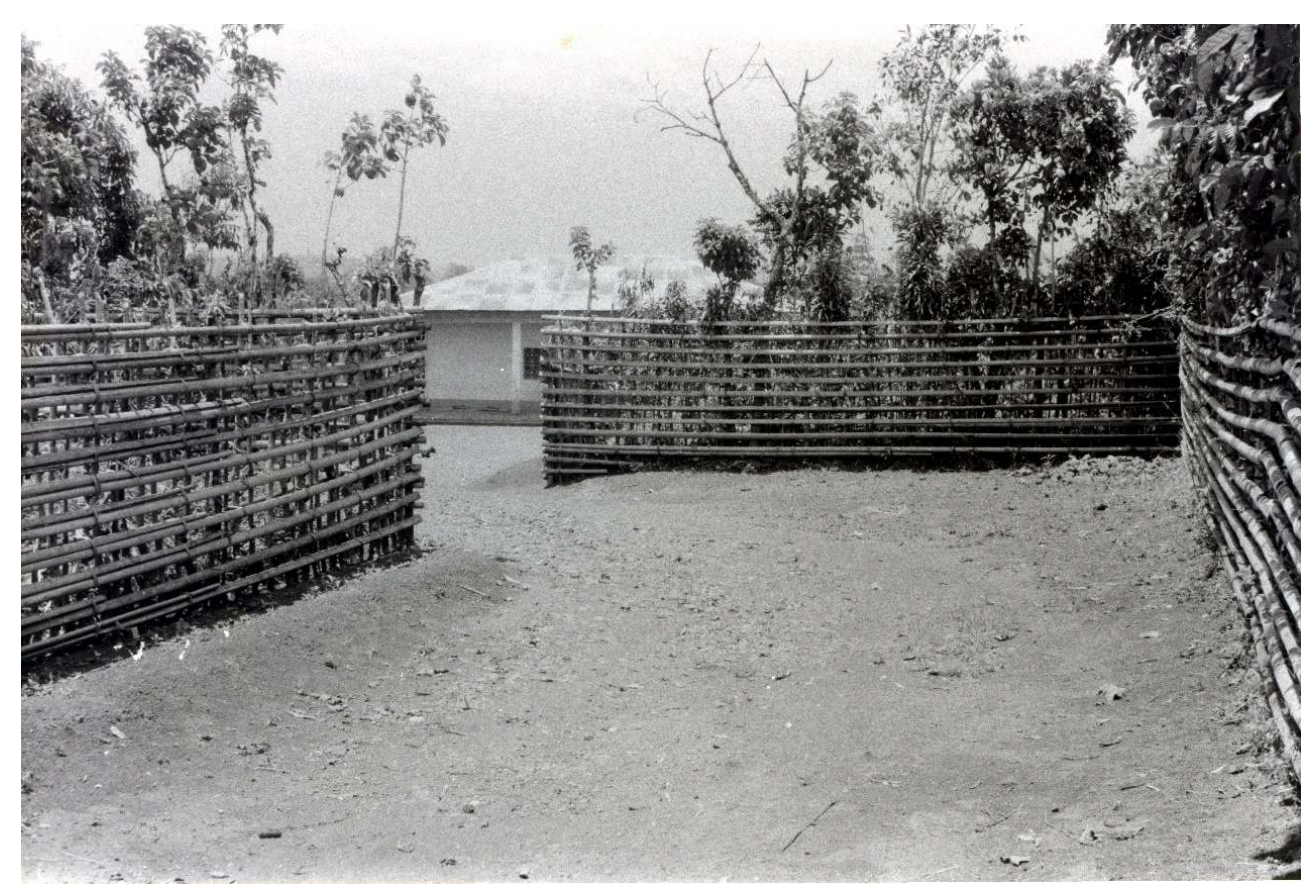

The hedgescapes (bocage) were becoming more widespread, but always started from the political and religious centres.

The Hurault analyses $(1962,1970 b)$ mentioned this organisation of the land (terroir) and distinguished between:

- the area covered by the concessions, whose plots and network of hedges are modernised to keep up with changes in the agrarian system, especially the connection between crop- and livestock-farming;

- and "the countryside" which is part of the unenclosed, more distant fields. 
Picture 5: Bamiléké landscape with a network of hedges around the concessions which have expanded to the hilltop (source: Gautier, 1991)

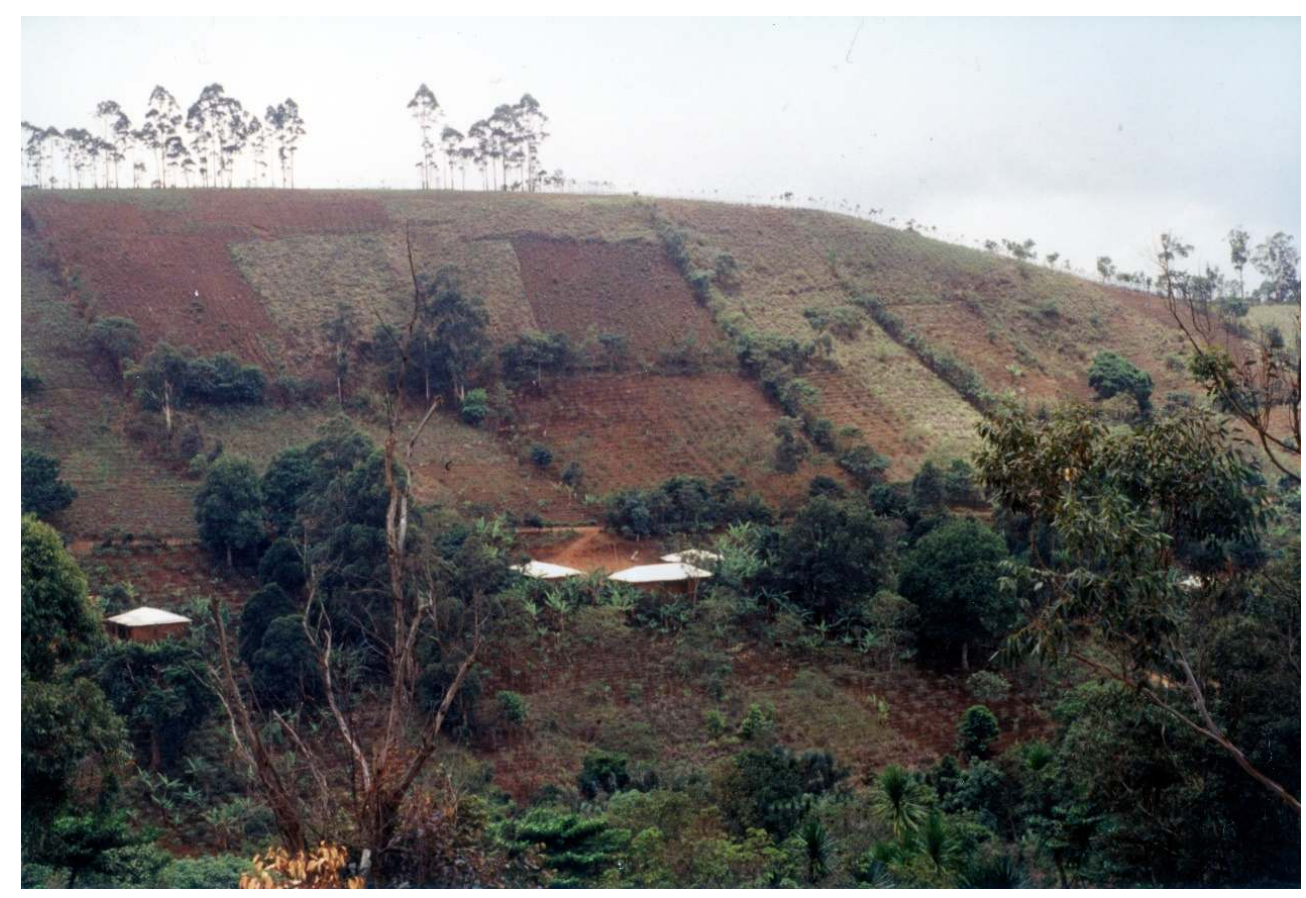

The efficiency of the hedge enclosure system was connected to the presence of sheep and goats which made it essential to hedge in the fields. Small ruminants were the source of capital accumulation for the Bamiléké farmers at the beginning of the $20^{\text {th }}$ century. Goat farming was the main resource for climbing up the social ladder (Hurault, 1970a). The biggest herds were located within the housing compounds belonging to the chiefs and notables, who ordered the farmers to install a tightknit network of hedges as lanes for routing livestock to the communal grazing grounds located at the top of the hills or in the high altitude savannas. The role of the notable was to organise the terroir and enforce respect for this organisation as a way to ensure equal access for all the inhabitants in the neighbourhood to the hills or the groups of hills they were given to share (Hurault, 1970a)

Maintaining the hedges and adding a supporting horizontal palisade of Raffia palm leaves required considerably painstaking work. If a single hedge could be crossed, the whole fencing system had to be examined (Barbier, 1988). As J. Hurault (Hurault, 1970a) wrote, no customary rule obliged anyone to maintain the hedges, at least not in all the chiefdom (named "groupements" by Hurault), and our studies did not confirm maintenance of hedges. On the other hand, social pressure on the chiefdoms was very strong and each year the senior chief used an age-based work group as a labour force (Hurault, 1970b) to keep up the hedges around the chiefdom. Since the most capable people left to find work elsewhere?, hedge maintenance was left to ordinary members of the chiefdom, who felt the job was almost impossible. This partly explains the enthusiastic reaction to the introduction of coffee plantations ${ }^{17}$.

The network of hedges at the centre of the chiefdom was tightknit for safety reasons. The concessionary lands were protected by border hedges, the cultivated fields were located on communal land and required authorisation from the local notables (Hurault, 1970a), or were located in the "countryside" were for temporary use and were not enclosed. 
The most important changes between 1915 and 1945 were the following:

- for the region: total pacification of the region and the establishment of permanent boundaries between the chiefdoms; accelerated population growth;

- for the chiefdoms: total occupation of the unoccupied lands between the quarters; reduction of grazing savanna; gradual occupation of the countryside ${ }^{18}$;

- for the concessions: total occupation of all available lands; land tenure fragmentation; relocation of houses near the top of the hills; reduction of grazed fallow;

- for the hedgescapes (bocage): intensification, in other words, increased hedge density; networks of hedges extended over nearly all of the chiefdoms (except the in the "countryside").

The traditional land use system based on mixed crop-livestock farming, with sheep and goats, was intensified to the point of near saturation. We hypothesise that between 1915 and 1945, the population reached a demographic threshold that required a more intense land development system (with more intensive bocage) and new solutions such as the rural exodus and more sophisticated production systems. After this period of "involution", the system could evolve and expand no further (Fig. 3).

Fig. 3: A graphic representation of the expansion and intensification of the Bamiléké bocage between 1910 and 1945

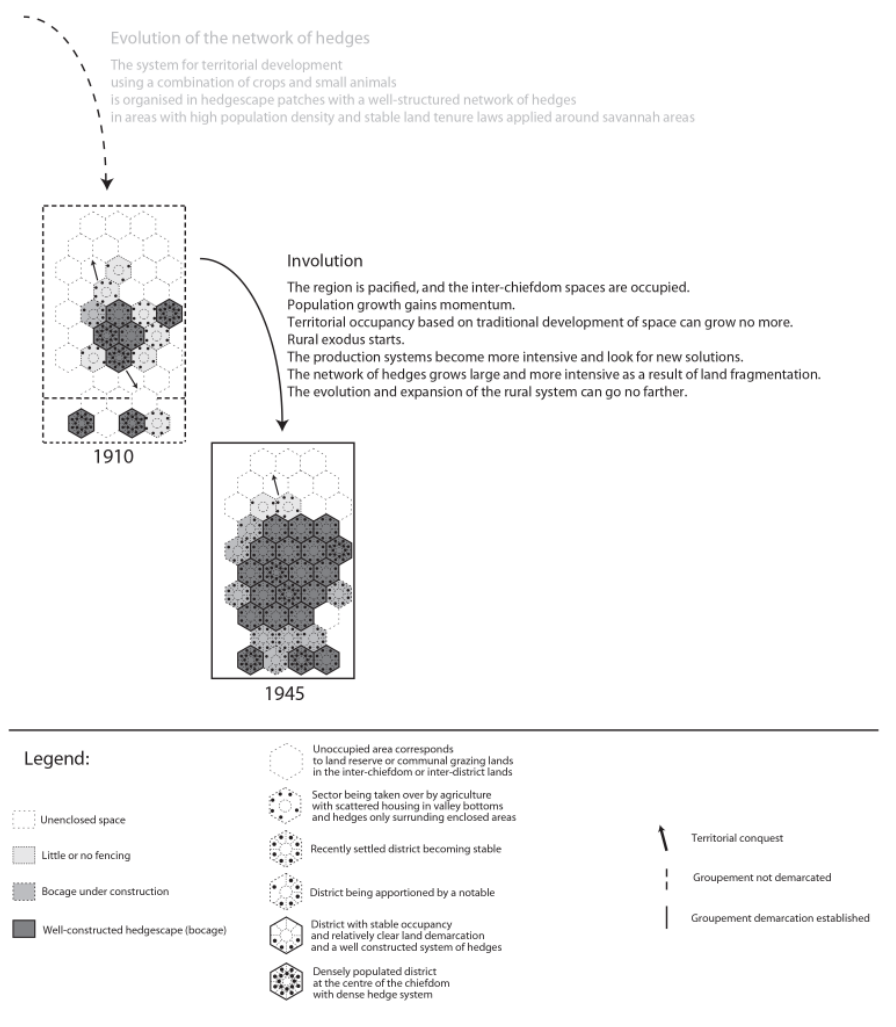

\section{Liberalisation of the coffee sector (1945-1960): the functional revolution of bocage}

61 The expansion of the coffee-growing area after 1945 led to the following landscape: increase in the number of trees in the fields, but removal of some fences since they were no longer needed and impeded efforts to expand the coffee-growing areas; disappearance of the crop/grazed fallow 
rotation; reduction of the tightknit network of hedges, although the hedges were kept at least to delineate land use rights. As a result, the bocage system even tended to expand as the population grew.

After World War II, uncontrolled coffee cultivation changed the wooded landscape. Coffee trees were first planted in 1927 and coffee production was regulated until 1945 (Dongmo, 1981). It was the private dominion of the notables. The plantations were located on the richest soils and were strictly regulated. Distribution was tightly controlled by the colonial agricultural service, more specifically by Largarde's men. According to the people we interviewed, Lagarde, an engineer serving at the Dschang experimental station, was famous among the farmers for being very strict. The colonial administration wanted to protect the lands that were earmarked for food crops.

After World War $\mathrm{II}^{19}$, and growing conflicts over land as a result of the increase in population and social conflicts, restrictions on coffee growing were lifted. In the 1960s, after independence, more land, actually up to $50 \%$ of the best arable lands in some places, was given over to coffee trees, (Hurault, 1970b). Small livestock, that had previously been a source of wealth, was replaced by the more profitable coffee trees. The whole farming system was changed by the decision to liberalise the coffee trade ${ }^{20}$. Less land was available for food crops, which women started cultivating under the coffee trees as of 1945 when the authorities lifted the ban on this practice. Herds became smaller as livestock suffered from epizootic diseases, less land was available for grazing high up on the hills, and the farmers' strategies changed.

One of the indirect consequences was a lesser felt need for hedges. The temporary 2-3 year-old hedges that had been used to corral the livestock and to organise the crop/ grazed fallow rotation disappeared.

This did not mean a reduction in the land area of the hedgescapes. Quite the contrary, these tended to expand in the areas between the chiefdoms, as a result of population growth. But the network of hedges became less tightknit as coffee trees occupied more space, and small livestock and consequentially fences disappeared within the concessions. Hedges were kept as part of the landscape to delineate the land rights of the concession operators, but were no longer used to combine or separate crops and livestock production. Their function changed, but not their vertical structure. 


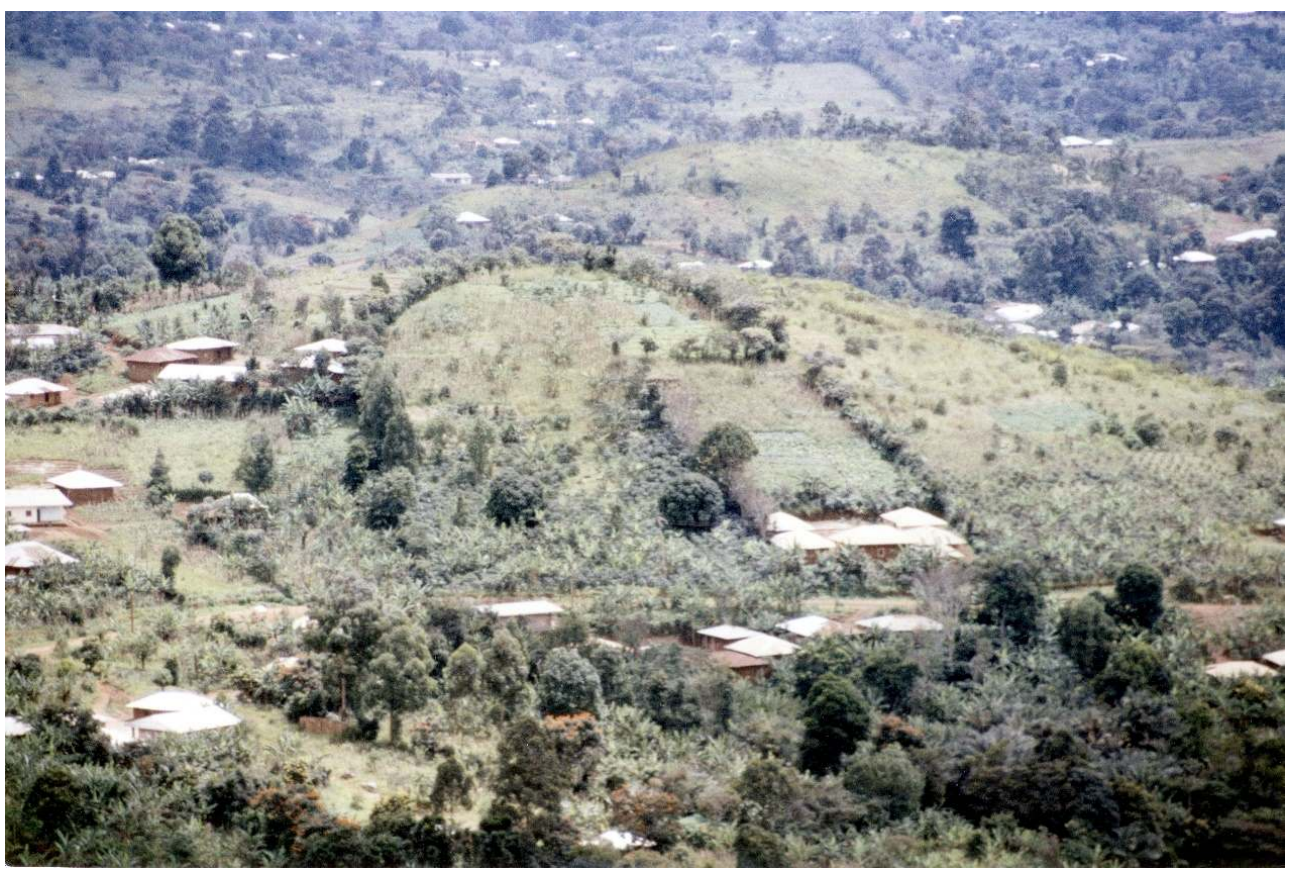

The large-scale introduction of coffee trees in 1945 had another positive effect on the treescape. It increased the presence of trees in cropped fields, insofar as the combination was not incompatible.

Before the arrival of the Europeans, agriculture meant food crops. Jean-Pierre Warnier (1984) suggested that slash-and-burn horticulture probably dated back to the Neolithic era and led to long-term habitation of certain lands that were used in a crop-fallow rotation. Population growth, which was no doubt stimulated by the introduction of American food plants, led to the bocage system [hypothesis formulated by J.-L. Dongmo (1981)] and agricultural intensification in the areas near the houses.

In these areas, where land tenure rights were clear, mixed cropping was often practiced (Albert, 1937; Despois, 1945). There was only one cropping season. But at the top of the slopes, groundnut crops were sometimes intercropped with maize or taro; whereas in the middle or lower areas, the basic combination was maize-tuber crops, and at the bottom of the valley beans were mainly intercropped with tubers. In the "countryside", food crops were intercropped at the pleasure of the communities, or else grown alone; they suffered from competition with the trees. But these crops were not excluded from the fields, quite the contrary.

Trees were not only identified as components of hedges and fences. Father Albert (1937) was interested in trees for their symbolic value; L. Hedin (1930) recorded the existence of trees (Canarium schweinfurthii, Cola anomala, Spathodea campanulata), sparsely dotting the farmlands of the savanna that were useful for the rural populations; and Despois (1945) wrote that: "a few scattered banana plants and perhaps a few kola trees can be found in the farmed areas".

70 Although tree density was not uniform throughout the region, there is no doubt about presence of trees in the fields. They were connected to people's need for food (fruit, kola) and forest products for consumption (a concern to never be short of wood) and social interaction. They were also connected to the regional economy. The Bamiléké people sold 
tubers, seeds, sheep, goats and kola nuts for palm oil produced in the low lying lands of the periphery. Warnier (1984) believed that large numbers of kola trees were planted after the kola trade started expanding in the second half of the $19^{\text {th }}$ century.

71 Shade trees were systematically planted, evenly spaced, on the best lands in the lower part of the concession to provide much needed shade for the coffee plants. One of these shade species, Leucaena glauca, was supplied by the agricultural services. In 1991, some of them were still standing along the roadside (Gautier, 1991). The introduction of coffee completely changed the production systems by reducing the land available for food crops. It led to the cultivation of more land and, in the first phase, to double cropping, which was not compatible with livestock production (Hurault, 1970b).

Around 1950, when the orders from the colonial agricultural services became less constraining, the farmers gradually replaced the imported shade trees by more familiar trees, in particular fruit trees. They also reintroduced subsistence crops in areas from which they had been expelled. To make the tree-coffee-food plant association viable, woody plants were pruned to respect the production requirements of the other crops.

How the farmers received an imported innovation (the dense shade trees) and adapted it to their traditional system of farming was critical to the changes in the landscape. The result of this assimilation was the close connection between the trees, the food crops and the cash crops. It is thus likely that the introduction of coffee did not only have a negative effect on the organisation of the agricultural systems. Coffee cultivation probably contributed to the design of complex tightknit agroforestry systems (Gautier, 1994b). As of 1945, the coffee growing area was expanded; fences were removed since they were no longer needed and were obstacles to the expansion of the coffee-growing areas. At the local level, the thickness of the hedges decreased as part of the "bocage revolution", but the hedges were kept at least to delineate land use rights. The bocage system even tended to expand with the increase in the population (Fig. 4). 
Fig. 4: A graphic representation of the functional revolution of the Bamiléké bocage between 1945 and 1960

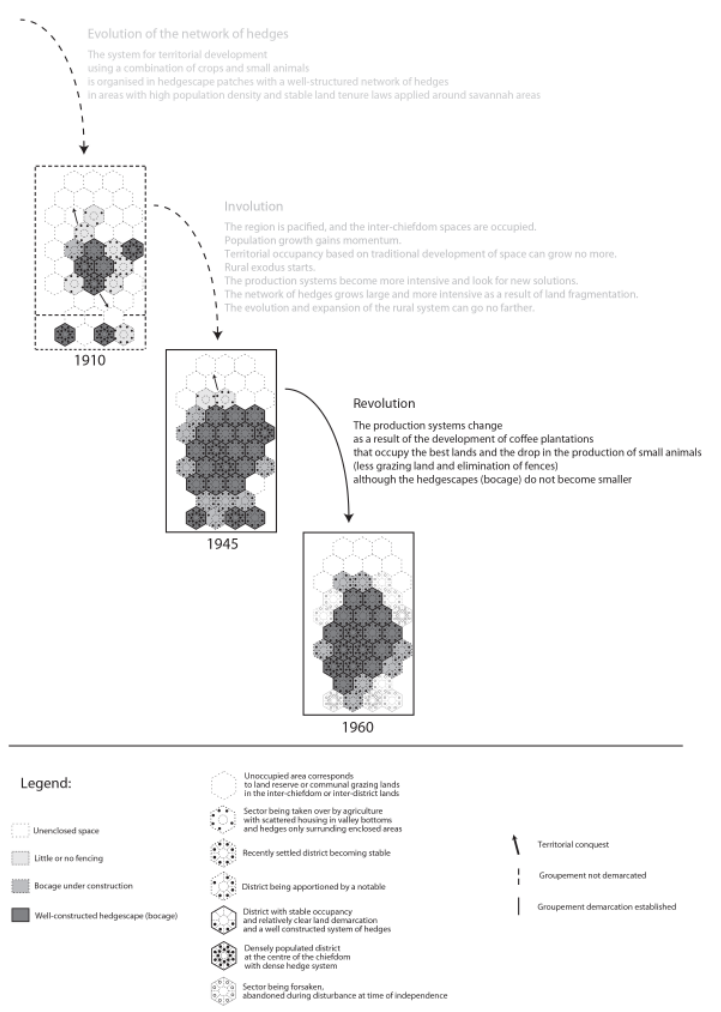

\section{A pause in the havoc surrounding independence (around 1960): partial destructuring of the bocage}

The size, but not the internal organisation, of the wooded landscape was still changing when Cameroon became independent. The arrival of the Europeans and the pacification of various chiefdoms resulted in the expansion of the hedgescapes; when the colonisers left, the hedgescapes shrank.

Little has been written about the conflicts that occurred around independence in Bamiléké region (1958-1962). Articles by journalists (Defresnes, 1960) and testimonies (Momo, 1986) report tremendous confusion about this period of violence: roads were blocked, plantations were laid waste, houses were wrecked or burned, and rebels destroyed the tickets d'impôts (tax receipts) ${ }^{21}$. The insurgency sparked off a civil war, and senseless destruction and violence. Analysing the consequences of this disturbing period is beyond the scope of this paper. For our study, the main consequence of these incidences was compulsory regrouping in most of the Bamiléké chiefdoms. The local people were obliged to spend the night in safe houses along the roads; the effects on the landscape were minimal. But in most cases, houses in remote areas were entirely destroyed and their inhabitants had to move to the cities. This type of regrouping left deep scars (Hurault, 1970b) and disorganised the agrarian systems. Whole regions were deserted and by 1990, had not yet been reinhabited, especially the areas between the chiefdoms. Even now people speak very little about - and only rarely allude to - this period. The scars left by this period discouraged the development of the bocage system. 


\section{Conclusion}

In this paper, we demonstrate that hedgescapes were an endogenous innovation that existed before the arrival of the first Europeans. Analysing the evolution of the bocage between 1900 and 1960, helps understand the dynamics and the impact of historical changes. The process was not linear. It was composed of waves of extension and withdrawal. At the beginning of the $20^{\text {th }}$ century, clusters of hedgerows were all that remained on the mainly savannah landscape where new systems were already established with the following characteristics: mixed crop/livestock farming systems, relatively high population density, scattered housing, independent farmers on land attributed to them by the local authorities. Between 1915 and 1945, the hedgerow system (bocage) quickly spread and dominated the landscape. The Bamiléké region appeared to have crossed a demographic threshold, thanks to European pacification and health care. As the traditional land development system could not accommodate further population growth, the farmers were obliged to organise their territory and install a well-organized system of enclosures all over the inhabited landscape. Coffee production, which was introduced by the French and combined with food crops, provided the farmers with an alternative cash crop that was part of the market economy. The best lands were used to grow coffee, not to rear livestock, which had been the traditional source of income. The enclosure system was gradually abandoned, and the hedges were mainly used to delineate allocated lands and as a source of woody and non-woody forest products. After 1945, the system continued to expand in the colonised areas, but later shrank in areas where conflict broke out in the early days of independence. It then expanded again, but sometimes in a modified form.

Thought needs to be given to the "revolution", the functional process that was initiated by the introduction of coffee. Hedges were maintained on lands that were often cultivated and sometimes enclosed. Between 1900 and 1960, the bocage system was affected by all the political, demographic, social and economic changes in the Bamiléké region, but survived. Trees are a permanent component of the landscape, and the treescape is not easy to change. But alone, this probably does not explain the resilience of the bocage system to so many disturbances. The peasants' culture must also be taken into account. This "hedge-strong culture" probably saved the bocage from the "involutions" and the "revolutions" and enabled its "evolution".

\section{BIBLIOGRAPHY}

Albert A., 1937, Cameroun Français au Pays Bamiléké. Bandjoun. Croyances, Coutumes, Folklore, Paris, Dillen.

Ankermann B., 1910, "Bericht Über eine Ethnographische Forshungsreise ins Grasland von Kamerun”, Zeitschrift für Ethnologie, No.42, 288-310.

Cybergeo : European Journal of Geography , Espace, Société, Territoire 
Barbier J.-C., 1981, Le peuplement de la partie méridionale du plateau Bamiléké. Contribution de la Recherche Ethnologique à l'Histoire des Civilisations du Cameroun, Paris, Centre National de la Recherche Scientifique.

Barbier J.-C., 1988, “Expansion et limite d'un bocage d'altitude : cas du pays Bamiléké au Cameroun”. IX Colloque SEPANRIT, L'Homme et la Montagne Tropicale, Yaoundé.

Buell R., 1965 (1928), The Native Problem in Africa, London, Frank Cass \& Co.

Calvert A. F., 1917, The Cameroons, London, T. Werner Laurie.

Champaud J., 1983, Villes et Campagnes du Cameroun de l'Ouest, Paris, ORSTOM.

Cornevin R., 1969, “The Germans in Africa before 1918”, in: Gann, L. , Duignan, P. eds.), Colonialism in Africa 1870-1960. Vol.I: The History and Politics of Colonialism 1870-1914, Cambridge, Cambridge University Press, 383-419.

Cornevin R., 1975, “Histoire de l'Afrique” in : Vol.III : Colonisation, Décolonisation, Indépendance, Paris, Payot.

Defresnes R., 1960, “Voyage au pays de la peur”, Afrique nouvelle, No.1659 and No.1660.

den Ouden J., 1980, "Incorporation in the composite household. The effects of coffee introduction and food crop commercialization in two Bamileke chiefdoms, Cameroon", in: Presvelou, C. , Spijkers-Zwart, S. eds.), The Household, Women, and Agricultural Development, Wageningen, Veenman \& Zonen, 41-67.

den Ouden J., 1981, "Changes in land tenure and land use in a Bamileke chiefdom, Cameroon 1900-1980 : an historical analysis of changes in control over people, land, and production", Essays in Rural Sociology in Honour of R.A.J. Van Lier, Wageningen, Agricultural University, 171-261.

Deschamps H., 1970, “France in Black Africa and Madagascar between 1920 and 1945”, in: Gann, L. , Duignan, P. (eds.), Colonialism in Africa 1870-1960. Vol.II: The History and Politics of Colonialism 1914-1960, Cambridge, Cambridge University Press, 226-250.

Despois J., 1945, “Des montagnards en pays tropical Bamiléké et Bamoun (Cameroun Français)”, Revue de Géographie alpine, Vol.T. XXXIII, No.Fasc.I

Dippold M., 1973, “L'image du Cameroun dans la littérature coloniale allemande", Cahiers d'Etudes Africaines, Vol.XIII, No.1, 37-59.

Dizain R., 1953, “Les facteurs de l'expansion bamiléké au Cameroun”, Bulletin de l'Association des Géographes français, No.1235-1236, 117-126.

Dongmo D., 1983, Les Cultures Maraîchères dans la Province de l'Ouest : Production et Commercialisation, Université de Yaoundé, Cameroon.

Dongmo J.-L., 1981, Le Dynamisme Bamiléké. T1 : Maîtrise de l'Espace Agraire, Yaoundé, Cameroon, CEPER.

Dongmo J.-L., Tsalefac M., Metangmo G., Tazo E., 1990, Bafou, une Grande Chefferie de l'Ouest Cameroun, Yaoundé, Cameroon, CEPER.

Egerton F., 1938, African Majesty. A Record of Refuge at the Court of the King of Bangangté in French Cameroons, London, Routledge \& Sons.

Emonts J., 1922, Ins Steppen- und Bergland Innerkameruns. Aus dem Leben und Wirken Deutscher Afrikamissionare, Aachen, Xaveriusverlag.

Eyongetah Mbuagbaw T., Brain R., Palmer R. H., 1974, A History of the Cameroon, London, Longman. 
Fotsing J.-M., 1998, Paysages de l'Ouest Cameroun : Approche Géographique des Dynamiques de l'Espace Rural par Télédétection Paris, Université de Paris 4, la Sorbonne, 750.

Gann L., 1975, “Economic development in Germany's African Empire, 1884-1914”, in: Duignan, P. , Gann, L. eds.), Colonisation in Africa 1870-1960. Vol.IV: The Economics of Colonialism, Cambridge, Cambridge University Press, 213-255.

Gautier D., 1989, Connaissances et Pratiques Agroforestières d'une Communauté Rurale. Exemple de la Chefferie Bafou (Ouest Cameroun) Montpellier, ESAT - ENGREF, 57.

Gautier D., 1991, Les Principales Espèces Ligneuses de Bafou (Ouest Cameroun) et leurs Utilisations, Paris, GRET.

Gautier D., 1992, "Haies Bamiléké et systèmes de production : l'exemple de la chefferie Bafou (Ouest Cameroun)", Les Cahiers de la Recherche Développement, Vol.1/1992, No.31, 65-78.

Gautier D., 1994a, "Fondements naturels et sociaux d'un bocage d'altitude : l'exemple Bamiléké", Natures, Sciences, Sociétés, Vol.2, No.1, 6-18.

Gautier D., 1994b, “La diversité des systèmes agroforestiers bamiléké et ses évolutions contemporaines", Journal d'Agronomie Tropicale et de Botanique Appliquée, Vol.XXXVI, No.2, 159-178.

Gautier D., 1996, "Poupées russes et montagnes Bamiléké. De la concession à la chefferie : emboîtement des structures et dynamiques spatiales en pays Bamiléké", l'Espace Géographique, No.2/1996, 173-187.

Ghomsi E., 1972, Histoire des Bamiléké des Origines à 1920 Paris, Université de Paris XIII, 303.

Hassert K., 1908, “Ertster Bericht über die landeskundliche Expedition der Herren Prof. Dr. K. Hassert und Prof. Dr. F. Thorbecke in Kamerun”, Mitteilungen aus den Deutschen Schutzgebieten, Vol.21, 3-12.

Hassert K., 1917, Beiträge zur Landeskunde der Grashochländer Nordwest-Kameruns: Erster Teil: Physische Geographie, Berlin, E. Mittler und Sohn.

Hausen K., 1970, Deutsche Kolonialherrschaft in Afrika: Wirtschaftsinteressen und Kolonialverwaltung in Kamerun vor 1914, Freiburg, Atlantis.

Hedin L., 1930, Etude sur la Forêt et les Bois du Cameroun sous Mandat Français, Paris, Librairie Larose. Hurault J., 1962, La Structure Sociale des Bamiléké, Paris, La Haye Mouton.

Hurault J., 1970a, “Essai de synthèse du système social des Bamiléké”, Africa, Vol.XL, No.1, 1-24.

Hurault J., 1970b, “L'organisation du terroir dans les groupements Bamiléké”, Etudes rurales, No.37-38-39, 232-256.

Ittmann J., 1925, Nana. Eine Erzählung aus Kamerun, Stuttgart, Evangelischer Missionsverlag.

Johnson W., 1970, “The union des populations du Cameroun in rebellion: the integrative backlash of insurgency”, in: Rotberg, R. , Mazrui, A. eds.), Protest and Power in Black Africa, New York, Oxford University Press, 671-692.

Kuczynski R., 1939, The Cameroons and Togoland: a Demographic Study, London/ New York/ Toronto, Oxford University Press.

Lebeuf J.-P., 1919, Les Bamiléké du Cameroun, 33-35.

Ledermann C., 1912, "Eine botanische Wanderung nach Deutsch-Adamaua”, Mitteilungen aus den Deutschen Schutzgebieten, Vol.25, 20-55. 
Mann O., 1912, "Die geologische Untersuchung des Dschang-Bezirk im Januar bis Juni 1911", Mitteilungen aus den Deutschen Schutzgebieten, Vol.25, 217-232.

Momo G., 1986, Informations sur le Terrorisme en Pays Bamiléké. Ses Causes et ses Effets, 56.

Mveng E., 1963, Histoire du Cameroun, Paris, Présence Africaine.

Nkwi P. N., 1989, The German presence in the western Grassfields 1891-1913. A German Colonial Account Leiden, The Netherlands, African Studies Center, 121.

Pillot D., Lauga Sallenave C., Gautier D., 2002, Haies et Bocages en Milieu Tropical d'Altitude : des Pratiques au Projet, Paris, GRET.

Roberts S., 1963, The History of French Colonial Policy 1870-1925, London, Frank Cass \& Co.

Rubin N. N., 1971, Cameroun. An African Federation New York, Praeger.

Tardits C., 1960, Les Bamilékés de l'Ouest Cameroun, Paris, Berger-Levrault.

Thompson V., Adloff R., 1975, “French economic policy in tropical Africa”, in: Duignan, P. , Gann, H. eds.), Colonialism in Africa 1870-1960, Vol.I: The Economics of Colonialism, Cambridge, Cambridge University Press, 127-164.

Thorbecke F., 1914, Im Hochland von Mittel-Kamerun. 1. Teil: Eindrücke und Beobachtungen, Hamburg, Friederichsen \& Co.

Van Slageren J., 1969, Histoire de l'Eglise en Afrique (Cameroun), Yaoundé, Cameroon, Ed. Clé.

Van Slageren J., 1972, Les Origines de l'Eglise Evangélique du Cameroun : Missions Européennes et Christianisme Autochtone, Leiden, Netherlands, Brill.

Warnier J.-P., 1984, "Histoire du peuplement et génèse des paysages dans l'ouest camerounais”, Journal of African History, Vol.25, No.4, 395-410.

Warnier J.-P., 1985, Echanges, Développement et Hiérarchies dans le Bamenda Pré-Colonial (Cameroun), Stuttgart, Franz Steiner Verlag Wiesbaden.

Wilbois J., 1934, Le Cameroun : les Indigènes, les Colons, les Missions, l'Administration Française, Paris, Payot.

\section{NOTES}

1. Like Bafou, for instance, the Batsingla and Fokamezou sub-chiefdoms have maintained a certain degree of autonomy, even today.

2. "The way the land is used makes the south of the Bamenda district look almost European. Plantations followed by more plantations, etc. And where the crop farming stops, the stock farming begins with rich grazing lands covered with animals (Müller 1905)" quoted by (Cornevin, 1975) see also (Hassert, 1908; Ittmann, 1925).

3. "Even after twenty years of official occupation and lengthy campaigns in different parts of the empire, there remained large areas where German authority was represented merely by soldiers and not by a regular civilian administration. In the remoter parts of Kamerun and in parts of East Africa, German authority was even more shaky." (Gann, 1975 p. 226)

4. "The economic exploitation of the Schutzgebiet-Kamerun was thus limited to the south, or $\mathrm{m}$ ore precisely to the 'forest' Cameroon ... Even before the establishment of political control, the German agents of the Woermann Company had taken note of the extraordinary fertility of the volcanic lands to the west of Douala and along the slopes of Mount Cameroon, north of Victoria. The idea of plantations was thus 'in the air' from 1885 onwards ... But the vast majority of the 
plantations was situated in the present-day West Cameroon (Southern Cameroons) in the region of Moungo to the west of Douala." (Cornevin, 1969)

5. But compared to southern Cameroon, there were not very many (Hausen, 1970). Mainly the Basel mission in Bali (founded in 1903), the Bagam mission (1911), the Pallotin mission in Dschang (1910) and the Ossing mission (1912). Furthermore, in 1913-1914, their membership was very small: Bali 91; Dschang 122; Bagam 10 (Fig. 1); Ossing 20 (Hausen, 1970 pp. 204-206). Van Slageren gave more precise details concerning the effects of the Basel missions (Van Slageren, 1972). He also added the Bandjoun mission, founded in 1913, and the Bana mission founded in 1914 (Fig. 1). He mentioned the following small detail: in Dschang, which was a Catholic "stronghold", there was a large community of Protestants who had fled Namibia and were called the "witboois" ("white boys" in Afrikaans). Was this the community from the Djutitsa farm?

6. The missions are in a weak position and identify with the colonial powers (Hausen, 1970 p. 230; Van Slageren, 1969; 1972 p. 99 \& 111).

7. "A Bamiléké chiefdom comprises a number of quarters with, likewise, hereditary chiefs. Tradi tionally these quarters form clusters of compounds, dispersed in the valleys, but for defense $r$ easons not far from each other. Often the quarters were separated by hills or swamps which were not cultivated." (Den Ouden, 1980 p. 43).

8. "For defense reasons houses were built close together down in the valleys of the chiefdom. It was only when French administration was established and slave raiding was really over that house-sites spread up the hill (including the enclosures of certain spots) reaching the hilltop in about 1950." (Den Ouden, 1981 p. 200).

9. "Before about 1915, there was much land not used for cultivation of food crops, but neverth eless in that period land for cultivation often was a closed resource." (Den Ouden, 1980 p. 45)

10. "The compounds were difficult to enter from the roads situated on the hillcrests because they were hidden in the valleys and often could only be reached by a tangle of very small pathways bo rdered by fences." (Den Ouden, 1980 p. 45)

11. "Goats were free to graze on the whole concession during the dry period ... From March to September they were enclosed on special plots in the area around the houses ..." (Den Ouden, 1981 p. 199). "Women and children had to stay within the inhabited area of the quarter with its endless enclosures, fenced areas ... Enclosures were not only necessary to prevent cattle from entering the plots under cultivation, but also to prevent strangers entering the inhabited area ..." (Den Ouden, 1980 p. 45)

12. This changed the traditional equilibrium: the chiefs were given more authority (e.g. to allocate land) which was no longer controlled through traditional mechanisms (Rubin, $1971 \mathrm{pp}$. 16-17).

13. "When the French went there in 1920, the slave-trade still flourished and (in) the center and east, certain groups had never been subjected to European influence ..." (Roberts, 1963 p. 371)

14. "It was only when French domination was established and slave raiding was really over that $t$ he house-sites spread up the hill (including the enclosures of certain plots) reaching the hilltop in about 1950." (Den Ouden, 1981 p. 200).

15. A few figures provided by Tardits (1960): the population was estimated at 360,000 in 1939. In 1934, the population aged 0 to 15 years old accounted for $44 \%$ of the total population. By 1954 , this figure had risen to $52 \%$. The conclusions of the Kuczynski study (1939) on the evolution of the Cameroonian population during the German occupation provided more conclusive information supporting the demography-based hypothesis. Referring to the estimates by the administrators and the medical surveys which he often feels are inadequate, Kuczynski argued that the population growth during the German period was low, e.g. the administration estimated the population of the (Bezirk) Dschang-Bare region to be 116,603 in 1908-1909 (p. 31). His very cautious conclusion was that "There seems to have been a consensus of opinion that the population of the Cameroons did not increase ... But these data were so scanty and were collected 
mostly with so little skill that it would be unsafe to use them at all for drawing any final conclusi on." (p. 64, our emphasis).

During the transition period (1916-1921), the impression was the same because of the stop to actions started by the Germans and because of an influenza epidemic in 1918 and 1919. A few figures on the Dschang region: "Country of N'kongsamba-Bare-Fumban. Population 148,833; deaths 14,740 (due to epidemic) ... The population of the Cameroons ... seems to be decreasing st ill further." (pp. 72-73, our emphasis).

In the beginning of the French period, the total population figures were disputed. The first census (1926) produced an unexpected result: the people counted in the census only accounted for about two-thirds of the people in the earlier estimates. In the Dschang region, for instance, the official figures dropped from 315,355 in 1924 to 235,672 in 1926! (p. 77-89). As of that year, the figure rose each year and the Dschang region is explicitly mentioned in the 1934 census report "The censuses, by names ... show an appreciable increase in the native population... , this growth affecting mainly the circumscriptions of Yaoundé, Dschang, Ebolowa." (p.83). But even if the French figures were not confirmed, in 1935, for instance, the total population of Cameroon was estimated at 2,513,517, in other words 5.7\% higher than in 1936 !

Nonetheless a certain tendency can be inferred from this in-depth population analysis: the Germans underestimated the total population (2,653,000 for German Cameroon) while, in the beginning of the French period, the figure was too high, probably because it was based on estimations for the regions which were best known at that time (especially on the coast, in the centre, and in the far north and, as of the 1920s, the mountainous regions in the west); while the effects of the vast sparsely populated regions, like the tropical forest and the Adamawa, on the total figures was always underestimated. The "well studied" more populated regions were subject to the hard impact of slavery and, thereafter, of European occupation: armed resistance, forced labour, the introduction of previously unknown diseases, etc. The total population there appeared to be stable and even to dwindle in the 1910-1920 period. But as of 1930, the "beneficial" effects, or even the "positive" effects of western colonisation could be felt. Population growth was strong and, from then on, under French influence, pacification of the economically most promising regions, medical care, agriculture, missionaries, etc. A population threshold had been reached, partly as a result of this colonisation. The French administration felt that the Bafoussam, Dschang, Yaoundé, Maroua and Yagoua regions were overpopulated. The 1938 report gives the following figures for the Bamiléké region: 48.7 hab. $/ \mathrm{km}^{2}$, Bafang: 40.1 hab./ km², Bafoussam: 83.6 hab. $/ \mathrm{km}^{2}$; Bangangté: 28.8 hab. $/ \mathrm{km}^{2}$ (Fig. 1). Bafoussam stands out because its population density is far higher than that of the other regions; interestingly, this is the region where the bocage/livestock production system was the most highly developed. This takes us back to what Warnier (personal communication) had to say about our perspective: a detailed regional analysis is needed because the circumstances are not the same everywhere.

16. Botanial research was carried out earlier in the Wouri estuary and on Mount Cameroon by two Englishmen, Gustav Mann (1861-1862) and Richard Burton (1861-1864) and other scientists. The research was expanded to cover all of the forest domain of southern Cameroon during the German occupation, with the Ledermann mission (1908) in the west and the Bertin mission (1917). The goal - primarily economic - was to find regions with an abundance of precious tree species.

17. "in a system in which food-crops are grown by women in a mixed cropping system, the ext ensive coffee plantation means a 'deus ex machina' for man compared to animal husbandry with its concomitant large scale enclosures ...". (Den Ouden, 1981 pp. 209-210).

18. And there is testimony to the opposite, e.g. Egerton (1938) concerning Bangangté in 1935: "Th ere is much uncultivated land, especially near Bangangté, covered with the elephant grass ... Vill ages are usually built in wooded hollows away from the road ..." (p.79) "Attached to each tang la (quartier) is a certain amount of uncultivated land, and this a sub-king can assign to anyone who 
has the need of it. Actually the amount of uncultivated land tends to increase. More and more $y$ oung men are leaving their homes and going to work elsewhere." (p.123) "Because land is not scarce, in spite of the relatively high density of population, there are few difficulties about land tenure." (p.136) (Egerton is an amateur ethnographer and photographer who spent a few months in the Bangangté chiefdom in 1935).

19. "The Africans were pressured into increasing their crop yields (but for export rather than for food) and into asserting individual ownership rights over their land." (Thompson, \& Adloff, 1975 p. 136). See also (Deschamps, 1970 pp. 241-243).

20. Tardits (1960 p. 111) gives the following figures for the Bafou chiefdom: for a population of 20,839, in 1952 there were 2,900,458 Arabica coffee plants. This is the highest per capita figure in the whole Bamiléké region.

21. Concerning the Bamiléké region alone: "seventy-four public schools ... were destroyed, as well as 3 hospitals, 46 dispensaries, about 40 bridges, and 12 agricultural stations. Over 750 kilometers of road were also destroyed or truncated and several hundred kilometers of telegraph line pulled down." (figures provided by the French Fond d'Aide et de Coopération, Oct.1962-Jan.1963, cited in (Johnson, 1970 p. 678). "In Bafang and Bafoussam, I saw holes in the road that were several meters long. On each side ... burnt out houses, whole regions with no inhabitants. Coffee plantations were cut to the ground. Many of them were abandoned" (Defresnes, 1960).

\section{ABSTRACTS}

This paper analyses the evolution of the Bamiléké bocage (hedgescape) between 1900 and 1960 . The process was nonlinear and consisted in waves of extension and withdrawal resulting from farmers' innovations and foreign influences. We distinguish four time periods, which we feel correspond to evolutionary phases of the wooded landscapes: the arrival of the Europeans (1900-1915), the period from European pacification to the liberalisation of the coffee trade (1915 to 1945), the period of liberalised coffee trade (1945 to 1960), and the period of havoc at the time of independence (around 1960). At the beginning of the $20^{\text {th }}$ century, clusters of hedgerows were all that remained in the mainly savannah landscape around settlements. Between 1915 and 1945, the hedgerow system quickly spread and dominated the landscape. The Bamiléké region appeared to have crossed a demographic threshold that required a more intense land development system with a more developed bocage. Coffee production, which was introduced by the French, provided the farmers with an alternative cash crop. The best lands were used to grow coffee, not to rear livestock, formerly the traditional source of income. The enclosure system was gradually abandoned, with hedges used mainly to delineate allocated lands and as a source of wood and non-wood forest products. After 1945, the system continued to expand in the colonised areas. But it later shrank in areas where conflict broke out in the early days of independence. It later again expanded, but sometimes in a modified form.

Cet article analyse l'évolution du bocage Bamiléké entre 1900 et 1960. Cette évolution n'a pas été linéaire et comprend des épisodes d'extension et de contraction en fonction des innovations paysannes et des influences étrangères. Quatre périodes sont ici distinguées qui correspondent à des phases d'évolution du paysage et de son couvert arboré : l'arrivée des européens (1900-1915) ; la période allant de pacification de la région par les Européens à la libéralisation du commerce du café Arabica (1915 to 1945) ; la période de libéralisation du commerce du café (1945 to 1960) ; et la 
période de rébellion au moment de l'indépendance (autour de 1960). Au tout début du $20^{\mathrm{e}}$ siècle, le paysage dominant était constitué de savane avec des tâches de réseaux de haie autour du siège des chefferies. Entre 1915 et 1945, le réseau de haies s'est rapidement répandu entre les chefferies et est devenu dominant dans le paysage. La région Bamiléké semble alors avoir atteint un seuil démographique qui induit un usage plus intensif de l'espace avec un bocage plus développé. La production de café, introduite par les Français, représente une nouvelle culture de rente pour les agriculteurs. Les meilleures terres sont désormais dédiées à cette culture et non plus à l'élevage comme précédemment. Le réseau de haies n'est de ce fait plus aussi nécessaire qu'avant et les haies sont désormais essentiellement des marqueurs de limites foncières et de sources de produits forestiers ligneux et non-ligneux. Après 1945, le réseau de haie, bien que moins dense, continue de s'étendre dans les espaces de colonisation agricole. Cependant, il rétrécie dans les espaces de conflits suite aux premiers jours de l'indépendance. Il s'étend ensuite à nouveau, mais sous des formes différentes.

\section{INDEX}

Mots-clés: agroécosystème, dynamique paysagère, nature/société, Bamiléké geographyun 903, 911, 120

Keywords: agroecosystem, landscape dynamic, nature/society, Bamiléké

\section{AUTHORS}

\section{DENIS GAUTIER}

(corresponding author)

Affiliation: CIRAD, UPR Forêts et Sociétés, Bobo-Dioulasso, Burkina Faso.

Forêts et Sociétés, Univ Montpellier, CIRAD, Montpellier, France.

Status: Research fellow

E-mail: denis.gautier@cirad.fr

\section{DIRK VERBOVEN}

Previous research assistant Anthropological Dpt, University of Gent, Belgium

\section{DAVID ANDREW WARDELL}

Affiliation: Center for International Forestry Research (CIFOR), France

Status: Senior Research Associate

E-mail: a.wardell@cgiar.org 